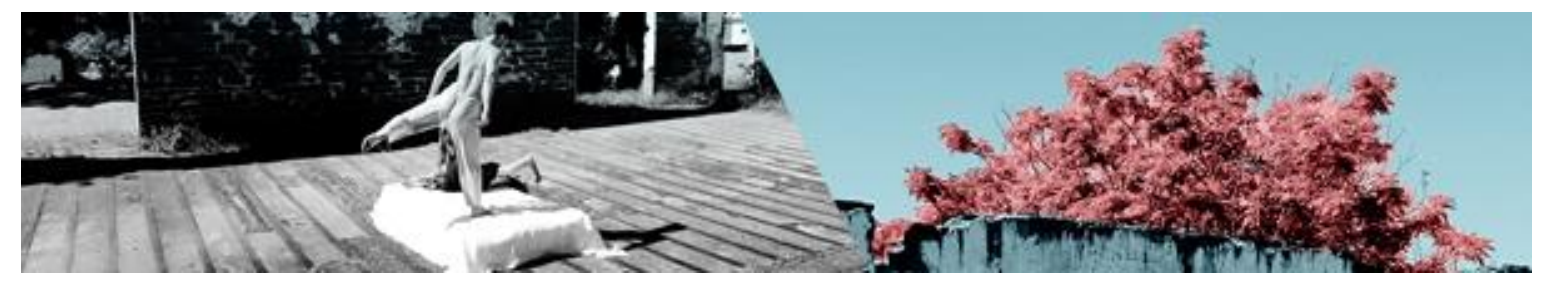

\title{
A PREÇO DE FÁBRICA: \\ PROPOSIÇÃO DA DANÇA CONTEMPOP NO CONTEXTO ESCOLAR
}

\author{
Djenifer Geske Nascimento ${ }^{1}$ \\ Daniel Aires $^{2}$ \\ Mônica Corrêa Barboza ${ }^{3}$
}

\begin{abstract}
Resumo: A Dança Contempop, elaborada por Berté (2015), surge da junção dos termos Dança Contemporânea e Cultura Pop e propõe a criação em Dança tendo como mote imagens popularizadas no cenário cultural contemporâneo. A partir desta proposição, este estudo analisa os procedimentos de criação da Dança Contempop no contexto escolar em uma experiência de práticas artísticas com duas alunas do Ensino Médio na cidade de Santa Maria/RS. Este estudo qualitativo percorre por discussões da Dança na Escola e busca inspiração na coreógrafa alemã Pina Bausch como ferramenta de autonomia e aproximação do contexto dos alunos nos processos de criação coreográfica.
\end{abstract}

Palavras-chave: Dança; Dança Contempop; Dança na Escola.

\section{A FACTORY PRICE: PROPOSAL OF CONTEMPOP DANCE IN THE SCHOOL CONTEXTO}

\begin{abstract}
The Contempop Dance developed by Berté (2015) comes from the combination of the terms Contemporary Dance and Pop Culture and proposes the creation in Dance having as motif images popularized in the contemporary cultural scene. From this proposition, this study analyzes the creation procedures of Contempop Dance in the school contexto, in an artistic practices experience with two high school students from the city of Santa Maria - Rio Grande do Sul state (Brazil). This qualitative study goes through discussions about the Dance in the School and seeks inspiration in the german choreographer Pina Bausch as a tool for autonomy and approximation to the students' context in the choreographic creation processes.
\end{abstract}

Keywords: Dance; Contempop Dance; Dance in the School.

\footnotetext{
1 Djenifer Geske Nascimento - Licenciada em Dança pela Universidade Federal de Santa Maria (UFSM) e acadêmica do Curso de Educação Especial (UFSM). Bailarina/pesquisadora no Laboratório Investigativo de Criações Contemporâneas em Dança (LICCDA) do Curso de Dança-Licenciatura da UFSM.

2 Daniel Silva Aires - Professor Substituto no Curso de Dança- Licenciatura da Universidade Federal de Santa Maria (UFSM). Mestre pelo Programa de Pós-Graduação em Artes Cênicas (PPGAC) da Universidade Federal do Rio Grande do Sul (UFRGS), Especialista em Dança (UFRGS) e Bacharel em Artes Visuais (UFSM). Artista/pesquisador na Cubo1 Cia. de Arte (Porto Alegre- RS).

${ }^{3}$ Mônica Corrêa de Borba Barboza - Professora Assistente do Departamento de Desportos Individuais, na Universidade Federal de Santa Maria (UFSM), vinculada aos cursos de Dança-Licenciatura e Educação Física-Licenciatura. Mestra em Educação pelo Programa de Pós-Graduação em Educação (PPGE) da Universidade Federal de Pelotas (UFPel), Especialista em Psicopedagogia pela Universidade Católica de Pelotas (UCPel), Pedagoga e Licenciada em Dança pela UFPel e artista da Dança.
}

NASCIMENTO Djenifer Geske; AIRES, Daniel; BARBOZA, Mônica Corrêa. A Preço de Fábrica: proposição da Dança Contempop no contexto escolar. Revista da FUNDARTE, Montenegro, p.222-241, ano 19, no 37, Janeiro/Março.

Disponível em: http://.seer.fundarte.rs.gov.br/index.php/RevistadaFundarte/index> 30 de março de 2019. 


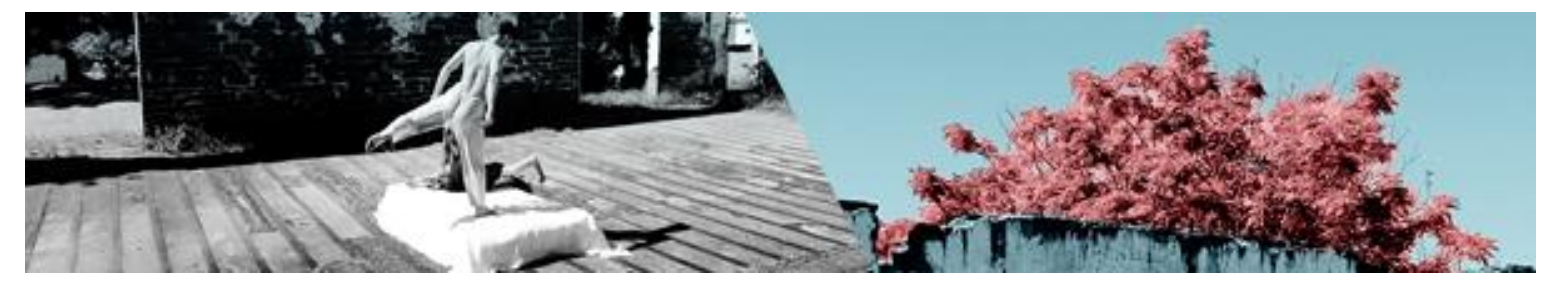

\section{Introdução}

O interesse pela Dança Contempop nos instiga a pensar na relação existente entre essa forma de criar Dança e o ambiente escolar com alunos do ensino médio, onde realizamos a criação da obra $A$ Preço de Fábrica (2018). Instigados pelas questões que engendraram este fazer e buscando a autonomia através da Dança chegamos até a questão que move esta escrita: como a Dança Contempop pode ser desenvolvida como proposta de criação com alunos de ensino médio? Os objetivos deste estudo são refletir sobre as possibilidades de desenvolvimento da Dança Contempop no contexto escolar, analisar o processo criativo e deflagrá-lo na perspectiva das práticas artísticas da Dança Contempop e das condutas inspiradas na coreógrafa alemã Pina Bausch (1940-2009), onde buscamos valorizar as experiências de vida dos alunos/bailarinos. A partir disso, o presente estudo foi dividido em três partes: a abordagem teórico-metodológica de Dança na Escola (MARQUES, 2010) e Dança Contempop (BERTÉ, 2015), a análise do processo criativo realizado, e, para concluir, a reflexão sobre a autonomia nos processos criativos e pedagógicos na área da Dança.

No caso da Dança, acreditamos em um ensino onde o aluno tenha oportunidade de vivenciar Arte na sala de aula, a partir do seu próprio fazer; uma aula de Dança em que ele tenha oportunidade de relacionar a sua prática com aspectos históricos, contextualizando-os nos mais diversos períodos da sociedade e conhecendo as mais diversas manifestações artísticas que existem no mundo.

Além disso, é essencial nesta aprendizagem que os alunos também possam ter momentos de apreciação e a oportunidade de fruir obras, analisá-las e construir novas questões acerca do conceito de Arte e do seu papel na sociedade. Marques (2010) relaciona o aprender Dança com o universo das palavras e da leitura. A autora se inspira em Freire (1970) para relacionar a alfabetização com o processo de aprendizado de Dança, e afirma que dançar não é só reproduzir repertórios, enfatizando a importância da apreciação/leitura como forma de compreensão, de forma não isolada, para não perder sua capacidade de transformação. É importante criar nexos; criar redes múltiplas entre os conhecimentos ligados ao fazer e ao apreciar com os contextos NASCIMENTO Djenifer Geske; AIRES, Daniel; BARBOZA, Mônica Corrêa. A Preço de Fábrica: proposição da Dança Contempop no contexto escolar. Revista da FUNDARTE, Montenegro, p.222-241, ano 19, no 37, Janeiro/Março.

Disponível em: http://.seer.fundarte.rs.gov.br/index.php/RevistadaFundarte/index> 30 de março de 2019. 


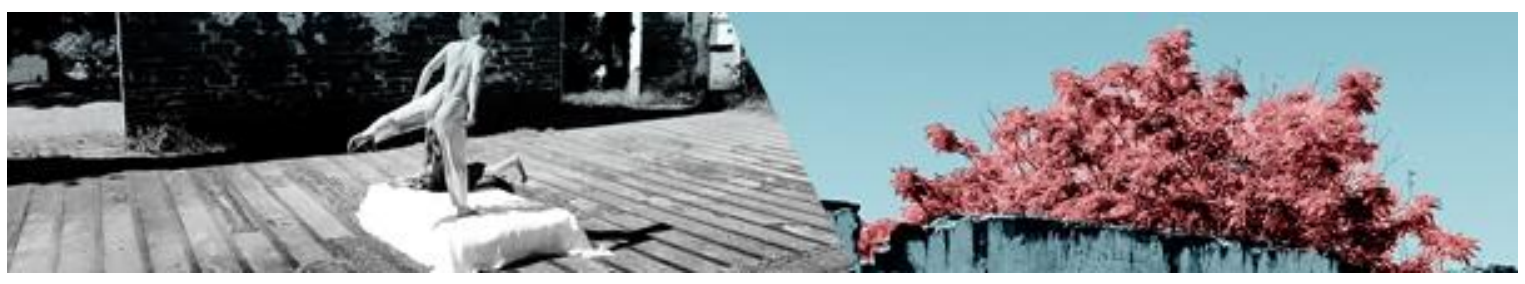

históricos, filosóficos e políticos passados, em comparação com o panorama atual onde a sociedade se insere.

É preciso uma Dança que provoque uma leitura crítica do mundo das interrelações, onde os estudantes sejam instrumentalizados a identificar e analisar de forma autônoma o que consomem. Ao se apropriarem de um conhecimento que lhes faça sentido, seja na área que for, possam formar opiniões próprias e seguir os seus próprios ideais, percebendo a multiplicidade de modos de existir. Na realidade, o que os professores encontram no espaço escolar é uma diversidade de perfis de jovens e crianças. Em concordância com Tomazzoni (2010) acerca das características dos alunos do ensino formal:

O aluno de Dança em uma escola faz parte deste perfil heterogêneo, que transita por uma cultura juvenil forte multifacetada, que vai de referências da mídia à cultura de rua. A escola, por sua vez, deixa de ser o único referencial para o conhecimento de dança. Estamos diante de uma realidade que coloca em jogo "um novo tipo de estudante, com novas necessidades e novas capacidades". (TOMAZZONI, 2010. p. 29).

Pensando na pluralidade do binômio necessidades/capacidades, assim como Marques (2010), acreditamos em um fazer Dança que instigue o aluno a desenvolver a autonomia criativa. Desejamos que se sinta motivado e instigado a buscar o novo, que seja inovador na sua prática profissional e que constantemente se reinvente em sua vida pessoal. Buscamos que ele atinja um estado de empoderamento para trilhar seu próprio caminho, independente das condições que lhe foram impostas. No entanto, o que comumente encontramos nas instituições escolares são práticas que não desenvolvem a autonomia, pois estão geralmente voltadas ao reprodutivismo sem levar em conta os saberes dos alunos. Freire (1970) denomina esta forma de fazer educação que não considera as vivências dos alunos como "educação bancária". O autor denuncia em seus escritos as contradições existentes nas práticas de educadores que querem propor uma prática libertadora, mas que compreendem seus alunos como seres que não possuem conhecimento algum. Acerca desta educação bancária ele ainda afirma:

NASCIMENTO Djenifer Geske; AIRES, Daniel; BARBOZA, Mônica Corrêa. A Preço de Fábrica: proposição da Dança Contempop no contexto escolar. Revista da FUNDARTE, Montenegro, p.222-241, ano 19, no 37, Janeiro/Março.

Disponível em: http://.seer.fundarte.rs.gov.br/index.php/RevistadaFundarte/index> 30 de março de 2019. 


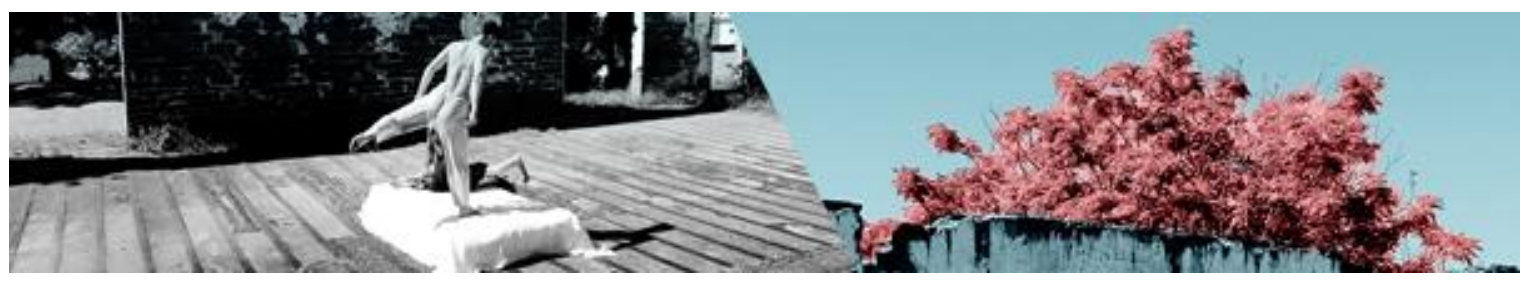

A educação que se impõe aos que verdadeiramente se comprometem com a libertação não pode fundar-se numa compreensão dos homens como seres "vazios" a quem o mundo "encha" de conteúdos; não pode basear-se numa consciência especializada, mecanicistamente compartimentada, mas nos homens como "corpos conscientes" e na consciência como consciência intencionada ao mundo. Não pode ser a do depósito de conteúdos, mas a da problematização dos homens em suas relações com o mundo. (FREIRE, 1970. p.38).

Para Freire (1970) este ensino autoritário e bancário é pautado por uma relação entre opressor e oprimido, onde os conhecimentos dos alunos não são valorizados, e os mesmos são considerados recipientes para que o professor deposite conteúdos. Para que uma educação libertadora ocorra, os opressores precisam ter consciência de suas contradições como educadores. Precisam entrar em um processo de autolibertação, para que possam propor uma prática dialógica, não bancária. 0 educador precisa estar aberto a mudanças e ter consciência do seu inacabamento, característica apontada por Freire (1996) enquanto própria da experiência vital. Para o autor "onde há vida, há inacabamento" (p.55).

A partir da reflexão acerca da educação bancária, Freire (1996) propôs um ensino com autonomia, baseada na escuta e no diálogo com os alunos. Também enfatizou a importância da autoridade sem autoritarismos por parte do educador, de modo que o aluno possa ter liberdade para assumir eticamente as responsabilidades de suas ações. Além disso, o autor afirma que é preciso respeitar os saberes dos alunos, especialmente os das classes populares. Silva (2009), inspirado em Freire (1996), acerca do aluno e do saber que ele já traz consigo afirma que:

O mundo que ele traz para dentro da escola precisa ser o ponto de partida para iniciar a construção de novos conhecimentos. São os pré-conceitos para começar a pensar. Nós não começamos a pensar do nada; em tese, sempre temos pontos de referências para estabelecer o vínculo entre o que sabemos e o que não sabemos. (SILVA, 2009. p.107).

$\mathrm{Na}$ escola, inspirados na pedagogia freireana, desenvolvemos uma Dança que pôde dar vazão aos conhecimentos que os alunos trouxeram de suas casas, ao mesmo NASCIMENTO Djenifer Geske; AIRES, Daniel; BARBOZA, Mônica Corrêa. A Preço de Fábrica: proposição da Dança Contempop no contexto escolar. Revista da FUNDARTE, Montenegro, p.222-241, ano 19 , ํo 37 , Janeiro/Março.

Disponível em: http://.seer.fundarte.rs.gov.br/index.php/RevistadaFundarte/index> 30 de março de 2019. 


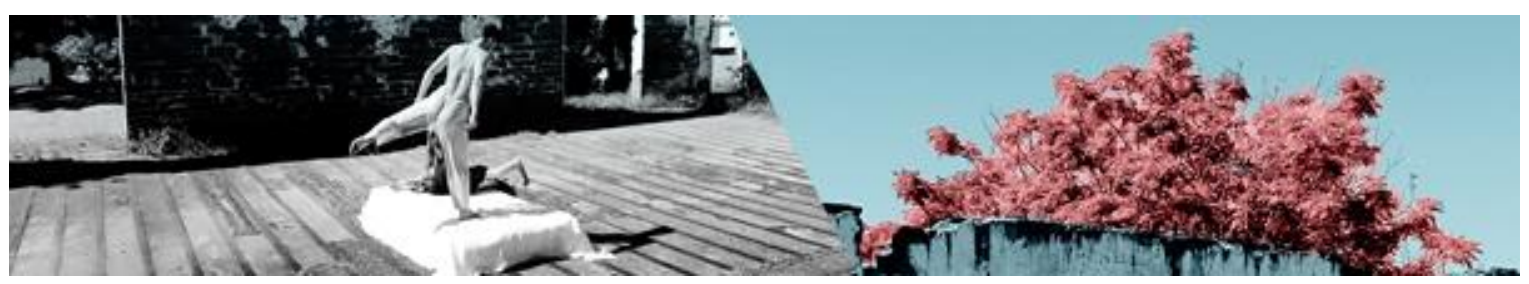

tempo em que puderam dialogar com os conhecimentos do professor. Quisemos contribuir na formação de sujeitos sensíveis através da Arte, acreditando na potencialização da subjetividade destes seres, concordando com o que nos apontam Marques e Brazil (2012):

"Inútil" e tratando do "incomunicável", a arte e o conhecimento na área de arte, assim, têm potencial não somente de ampliar e diversificar relações e relacionamentos, mas, sobretudo, de aprofundar e eventualmente transformar a visão monocórdica do consumo descabido, da ganância sem ética, de fins que justificam meios vexatórios, escandalosos e desrespeitosos. (MARQUES e BRAZIL, 2012. p. 35).

Sobre uma forma de dançar que se formule enquanto possibilidade na escola, pensamos que um caminho inspirador fosse uma Dança com abordagem contemporânea. Quando nos referimos ao termo abordagem contemporânea inferimos que, através deste olhar, poderíamos tornar o espaço da sala de aula um lugar para instigar a autonomia dos alunos, de forma que pudessem se autoexperimentar sem préjulgamentos, respeitando suas limitações e seus afetos. Thereza Rocha (2012) fala sobre um possível ensino da Dança que instigue a autonomia do aluno e discorre a respeito desta abordagem contemporânea:

Uma pedagogia da autonomia (Paulo Freire) em dança talvez seja uma pedagogia com dança contemporânea: via de passagem da heteronomia à autonomia, aquela que permite ao aluno pôr-se no mundo de um outro lugar como uma diferença que faz diferença. Trata-se de uma qualidade de percepção de si no/com o mundo que, uma vez experienciada, acompanha, em estado de latência, o aluno por toda vida - uma vida artista baseada na autonomia, na capacidade de pisar no chão a partir de si.(ROCHA, 2012. p. 46).

A referida autora não prescreve necessariamente o ensino de uma linguagem em Dança Contemporânea, mas usa o termo "com Dança Contemporânea". Ao refletir sobre qual seria esta Dança democrática e autônoma recordamos do que Marques (2010) - depois de ter questionado essa forma de arte - disse sobre danças que pronunciavam o mundo:

NASCIMENTO Djenifer Geske; AIRES, Daniel; BARBOZA, Mônica Corrêa. A Preço de Fábrica: proposição da Dança Contempop no contexto escolar. Revista da FUNDARTE, Montenegro, p.222-241, ano 19, no 37, Janeiro/Março.

Disponível em: http://.seer.fundarte.rs.gov.br/index.php/RevistadaFundarte/index> 30 de março de 2019. 


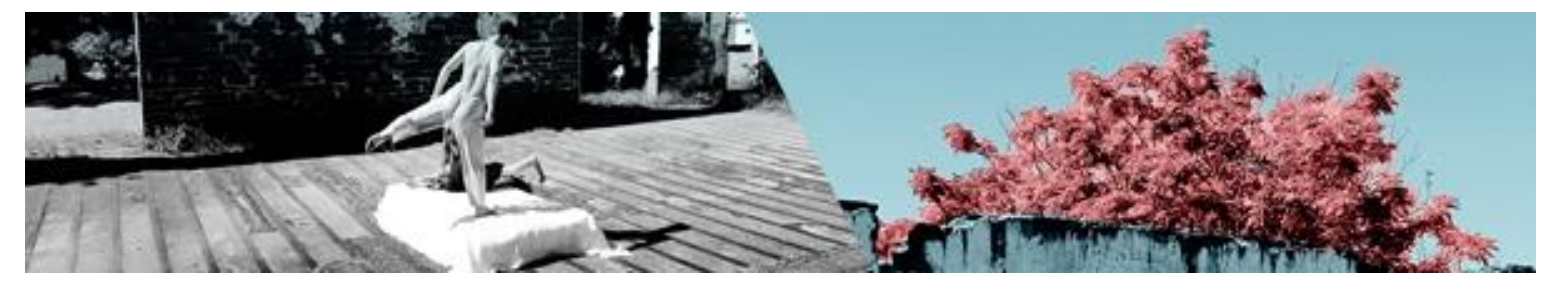

Quais/como seriam as propostas para o ensino e aprendizado da dança voltadas para a pronúncia do mundo? Considerando o pensamento de Paulo Freire educar é pronunciar o mundo, é articular o mundo, é ser permeável às vozes dos alunos em proposições dialógicas. Portanto, pronunciar o mundo é o mesmo que se relacionar com ele. (MARQUES, 2010. p. 134).

Acreditamos que todas as formas de Dança dialogam com o mundo de modo intrínseco, no entanto, isso não quer dizer que há uma pronúncia. Uma Dança que simplesmente se omite com relação à vida real, também constrói um diálogo, mas de omissão. É na busca dos aspectos relacionais das vivências dos escolares e de suas pronúncias de mundo que justificamos o interesse deste estudo.

Nesta pesquisa buscamos refletir de que forma uma criação artística pode estar composta de vivências dos alunos. Com isso a compreendemos sob o viés qualitativo de Bogdan e Biklen (1994) no âmbito educacional e na natureza do contexto do estudo, uma vez que os autores "entendem que as ações podem ser mais bem compreendidas quando são observadas no seu ambiente habitual de ocorrência" (p.48). Ainda na perspectiva pós-positivista (qualitativa), a análise dos procedimentos de criação aqui adotados, sobre a pesquisa em práticas artísticas, se explica a partir de Dantas (2007), enquanto uma investigação que se realiza em espaços de prática artística, como os ateliês, salas de ensaio, teatros e outros espaços de interação entre artistas e público.

Ainda enquanto estratégia teórico-metodológica que perpassa as práticas artísticas, adotamos a A/r/tografia de Dias e Irwin (2013), pois os autores compreendem que essa abordagem ressalta o potencial da arte enquanto espaço, sujeito e objeto, capaz de deflagrar a construção de saberes e conhecimentos, seja no contexto escolar, seja na área artística.

\section{Dança Contempop e uma possibilidade de criação a ser levada à escola}

Contempop diz respeito a uma proposição criativa que busca aproximar dois campos: Dança e Cultura Visual. Quando se refere à Cultura Visual, Berté (2015) explica que o foco dado diz respeito às relações que os sujeitos constroem com as imagens. $O$ autor afirma que: 


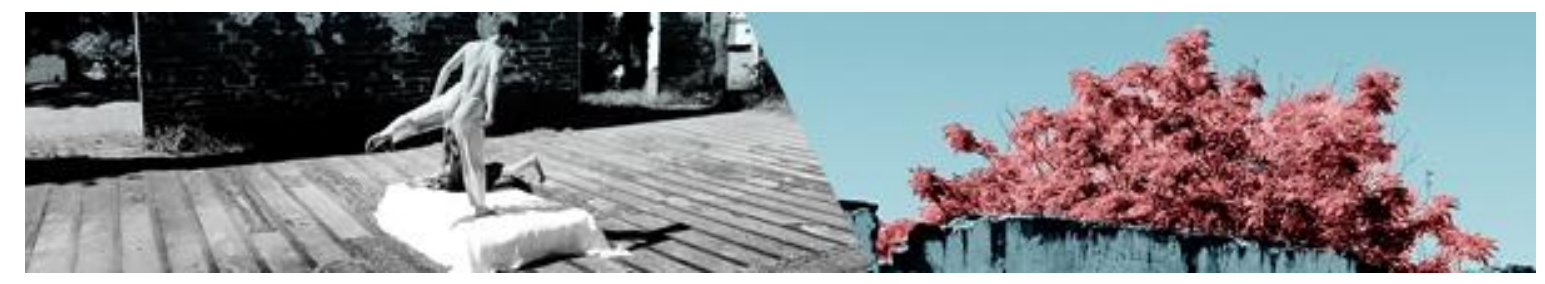

A Cultura Visual ressalta os modos como os corpos se relacionam com estes artefatos e com essas imagens, os usos que fazem desses e os significados que lhes atribuem em meio aos complexos e diversificados contextos dos quais faz parte. (BERTÉ, 2015. p.10).

De acordo com Berté (2015) o nome Contempop une os termos "Dança Contemporânea" e "Cultura Pop", sendo a primeira um termo que no entendimento do autor não diz respeito a um gênero ou estilo de Dança, mas a uma dinâmica de quebra de fronteiras pré-estabelecidas. Berté (2015) se reporta a alguns autores para explicar seu ponto de vista acerca desta Dança, dentre estes Katz (2004). A autora diz que, para esclarecimento do que é ou não dança contemporânea, é preciso observar se a obra faz uma pergunta, se ela indaga; ou seja, se ela afeta de forma negativa ou positiva o espectador. Já a Cultura Pop é compreendida como um movimento originário na década de 60 que esteve intimamente ligado ao modo de vida das pessoas daquela época (BERTÉ, 2015). É uma "manifestação cultural essencialmente ocidental, nascida no contexto de uma sociedade industrial capitalista e tecnológica" (OSTERWOLD, 2011, p. 06). Berté (2015) utiliza a cantora Madonna como exemplo desta manifestação, afirmando que tanto o pop quanto a artista buscaram desgarrar-se do formalismo da arte moderna, utilizando a experiência do cotidiano, objetos industrializados e a fisicalidade do corpo para aproximar a arte da vida. A arte que até então estava presente em locais específicos "passa a ser exposta, espalhada e replicada pelo mundo, rompendo convenções e formatos privilegiados pelas belas artes, pela estética e pelas filosofias clássicas e modernistas" (BERTÉ, 2015. p.97).

A Dança Contempop trabalha de modo criativo e pedagógico com as experiências dos bailarinos. Nos procedimentos de criação ocorre na relação corpoimagem. Em Berté (2015) o conceito de imagem é compreendido como artefato, como ideia e como ação do corpo. Como artefato, o autor entende essa imagem não apenas como representação, mas também como "vivência/experiência/afetividade articuladora de significados existenciais e simbólicos" (BERTÉ, 2015, p.136). Ele adiciona que, seja "vendo ou criando imagens, os corpos podem narrar-se por meio delas e pelos modos como as usam ou thes atribuem significado" (p. 136). Para explicar o conceito de imagem-ideia o autor se reporta a Damásio (2009), quando o mesmo explica que NASCIMENTO Djenifer Geske; AIRES, Daniel; BARBOZA, Mônica Corrêa. A Preço de Fábrica: proposição da Dança Contempop no contexto escolar. Revista da FUNDARTE, Montenegro, p.222-241, ano 19 , ํo 37, Janeiro/Março.

Disponível em: http://.seer.fundarte.rs.gov.br/index.php/RevistadaFundarte/index> 30 de março de 2019. 


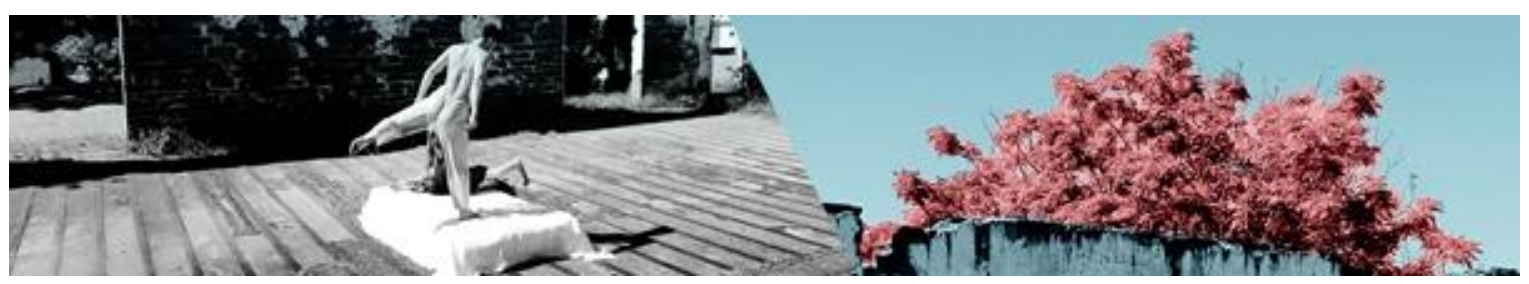

imagens de distintos gêneros atuam como modelos que se relacionam conscientemente a alguma coisa, como concepções e representações (DAMÁSIO, 2009). A imagem neste entendimento pode ser instaurada na relação com objetos, corpos, lugares e recordações a partir da memória. Já como imagem-ação o autor compreende o corpo como metáfora, ou seja, a ação corporal enquanto imagem.

A Dança criada a partir da relação do corpo com imagens artefato-ideia-ação coloca as experiências dos bailarinos em evidência, dando a oportunidade de serem também criadores. Na escola, instituição onde o ensino "bancário" e reprodutivista tradicionalmente predomina, criar com a proposição de Dança Contempop poderia auxiliar os estudantes a desenvolverem autonomia. Tourinho e Martins (2013) afirmam que "os estudos da cultura visual analisam fenômenos populares altamente entendidos como culturais". Levando em conta o que Freire (1996) diz acerca da valorização dos saberes oriundos das classes populares, podemos supor que relacionar Dança e Cultura Visual, utilizando mais especificamente a proposição citada acima, poderia ser uma forma de fazer com que os alunos tenham identificação com as criações realizadas no espaço escolar.

Berté (2015), ainda que não prescreva uma receita pronta para seus procedimentos de criação, ressalta alguns princípios para esta metodologia. O primeiro diz respeito a ouvir o que o corpomídia tem a dizer, sem estabelecer de antemão códigos pré-estabelecidos. Para que isto ocorra, o autor destaca a importância do professor/coreógrafo estar receptivo às danças dos alunos sem pré-julgamentos e sem receio de que tais elementos pareçam simplórios, clichês e/ou ingênuos. O segundo diz respeito ao professor/coreógrafo estar aberto a convidar 0 aluno/dançarino a rememorar, investigar e compartilhar seus afetos. Importa que o primeiro articule proposições que façam este segundo perceber os modos como afeta e é afetado, contamina e é contaminado; isto é, obtendo consciência da forma como a cultura educa e constrói sua subjetividade. O terceiro e último princípio tem relação com a montagem/edição do material criado, na qual se ressalta a importância de abrir a escuta nos momentos de edição coreográfica ou organização dos elementos. O autor ressalta que a "diversidade emergida das experiências não deve ser engolida por padrões NASCIMENTO Djenifer Geske; AIRES, Daniel; BARBOZA, Mônica Corrêa. A Preço de Fábrica: proposição da Dança Contempop no contexto escolar. Revista da FUNDARTE, Montenegro, p.222-241, ano 19, no 37, Janeiro/Março.

Disponível em: http://.seer.fundarte.rs.gov.br/index.php/RevistadaFundarte/index> 30 de março de 2019. 


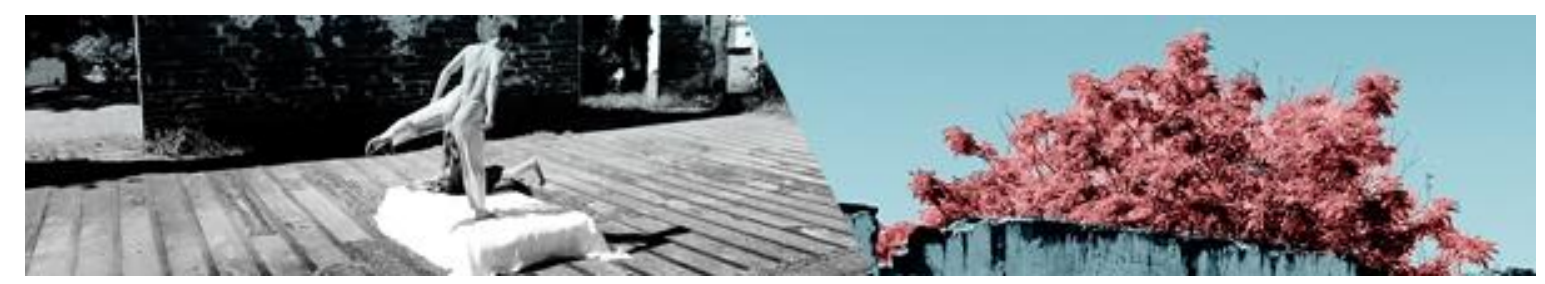

estéticos já existentes, mas deve inventar outros padrões ou adaptar os já existentes a seu bel prazer", importando a esta proposição "desestabilizar certos arranjos já organizados anteriormente e promover o aparecimento de novas metáforas, imagens artefatos-ideia-ação" (BERTÉ, 2015. p. 152).

Tendo como base estes princípios, construímos o nosso próprio conjunto de procedimentos. Ainda ao campo de aberturas de estruturas propostos pelo autor, aliamos o desejo - em tom de justificativa para este estudo - de uma proposição que possa colaborar na construção de um ambiente onde o ensino seja democrático, em que o respeito entre as pessoas e seus saberes prevaleça, independente de seu contexto de origem, reafirmando a importância da edificação de uma Dança que não se omita ao mundo, mas que em diálogo, se pronuncie.

\section{O processo de criação}

No desenvolvimento dos procedimentos aqui analisados contamos com a participação de duas jovens, Brenda Flores e Taciane Vieira, nominadas neste estudo afim de que se reconheça suas participações ativas. Ambas são alunas do ensino médio da Escola Estadual Professora Margarida Lopes na cidade de Santa Maria - RS. O processo criativo ocorreu no período entre os meses de setembro e novembro de 2018, em encontros que ocorreram duas vezes por semana, cada um com duração de uma hora e quinze minutos. Neste período foram feitos registros fotográficos e audiovisuais do processo criativo, além da produção por parte das alunas de um diário semidirecionado, envolvendo questões formuladas com espaço para relatos, desenhos, poesias ou algum outro tipo de manifestação que poderia suprir as necessidades das alunas sobre suas sensações ao longo da criação. A experimentação resultou na concretização da obra de Dança A Preço de Fábrica, apresentada no ano de 2018.

No primeiro procedimento de criação foram utilizadas imagens dos artistas preferidos das intérpretes-criadoras - os quais poderiam ser músicos, compositores(as), poetas, artistas plásticos, escultores(as), ator/atriz, artista circense, bailarino(a), performer, coreógrafo(a) ou diretor(a) de cinema. O intuito foi fazer um "diagnóstico" 


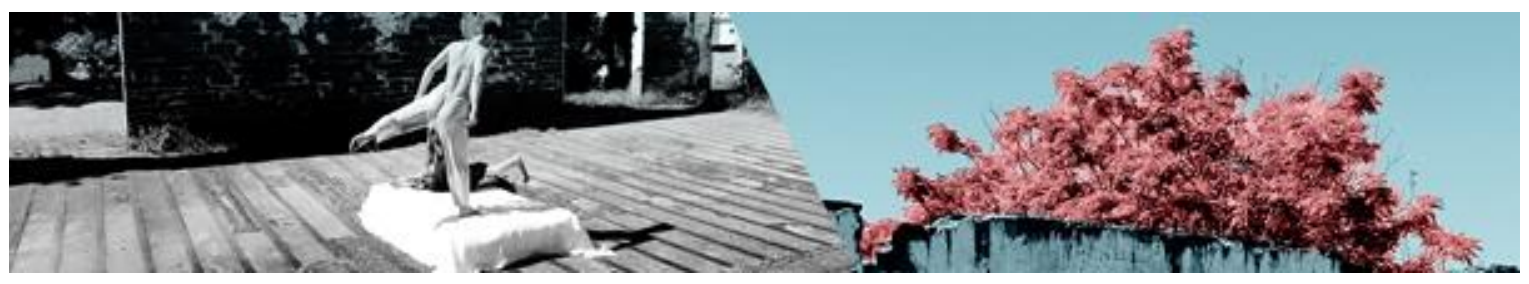

acerca dos gostos destas alunas e do que elas consumiam no dia-a-dia, e ao mesmo tempo instigar que estes gostos se tornassem mote para a criação em Dança.

Ambas as artistas escolhidas para a realização deste procedimento pertencem ao universo da música pop americana. A aluna Brenda escolheu uma imagem da cantora Rihanna em um de seus shows, na qual a artista sorri olhando para um ponto específico com as palmas de suas mãos encostadas, num gesto semelhante ao ato de rezar. Taciane, por sua vez, escolheu uma imagem da cantora Katy Perry, também na ocasião de um show, no qual a cantora usa uma vestimenta com transparências e pontos brilhosos, remetendo a um cenário futurístico, tecnológico.

As alunas tiveram a tarefa de escolher individualmente três palavras que resumissem suas imagens, elencando ainda um movimento para cada palavra, e pensando no significado que cada uma tinha para elas. A partir das imagens trazidas e interpretadas pelas alunas evocamos as reflexões de Berté (2015), em sintonia ao que Tourinho (2012) aponta sobre ver e ser visto nas imagens consumidas:

É possível ao corpo ver-se nos significados que atribui às imagens. Nessa relação o corpo pode se perceber, reconhecer-se nos modos como usa, interpreta, interroga, aceita ou repele a imagem, pois tais atitudes, dizem sobre quem ele é, no que ele acredita, pensa e gosta e sobre os grupos e lugares culturais aos quais ele pertence .(TOURINHO, 2012. p.156).

Segundo o autor, tanto a escolha das imagens quanto à forma como são interpretadas, diz respeito à visão de mundo que as pessoas possuem. No caso deste processo, Brenda e Taciane falam de si ao escolher e refletir sobre estas imagens. Podemos inferir, portanto, que a partir do momento em que começarem a ter consciência desse entendimento poderão conhecer mais de si mesmas, refletindo sobre os motivos pelos quais consomem o que consomem, pensando em possíveis significações, e sobre o que isso diz sobre suas personalidades.

Para o segundo procedimento, solicitamos que as alunas tirassem um print (captura de tela) dos seus cinco últimos compartilhamentos na rede social Facebook e trouxessem para o encontro, compartilhando-os com a colega, que deveria reagir a ele com um emoji do acervo de seu telefone celular. Os emojis eram desenhados em uma NASCIMENTO Djenifer Geske; AIRES, Daniel; BARBOZA, Mônica Corrêa. A Preço de Fábrica: proposição da Dança Contempop no contexto escolar. Revista da FUNDARTE, Montenegro, p.222-241, ano 19, no 37, Janeiro/Março.

Disponível em: http://.seer.fundarte.rs.gov.br/index.php/RevistadaFundarte/index> 30 de março de 2019. 


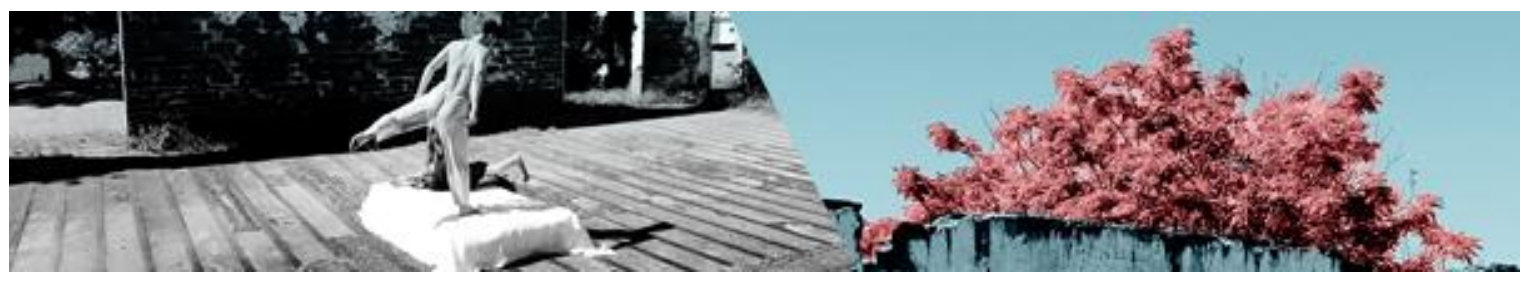

folha de caderno identificando a quais imagens se referiam. Em seguida, as alunas deveriam materializar essa imagem em uma pose, e a expressão facial deveria ser a mesma da reação da colega. Depois disso, foi composta uma sequência com as poses resultantes das imagens. Abaixo, encontram-se dois quadros (figura 1). À direita, o meme que Brenda trouxe, e à esquerda um registro fotográfico da jovem que se encontra experimentando poses para a imagem.
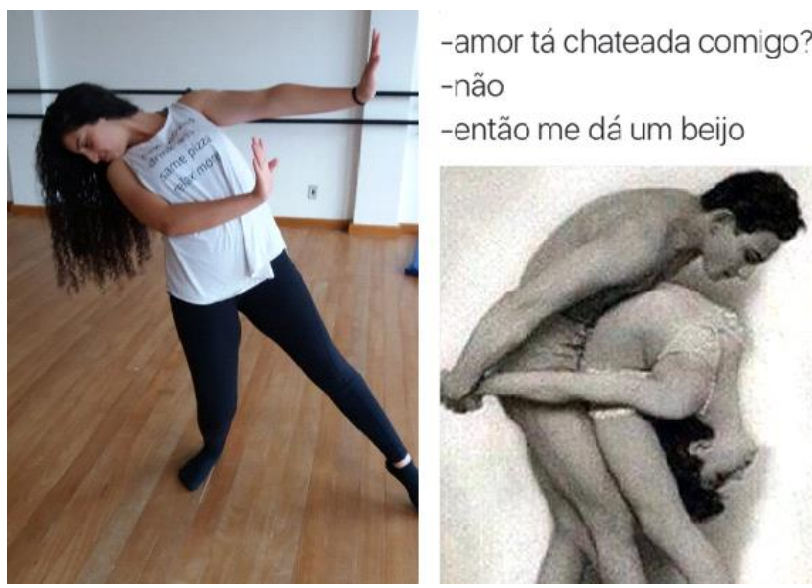

Figura 1. À esquerda a jovem se encontra experimentando poses para a imagem, e à direita o meme escolhido por Brenda. Fonte: Registro dos autores.

Taciane por sua vez, escolheu uma imagem com o tema semelhante ao de Brenda:

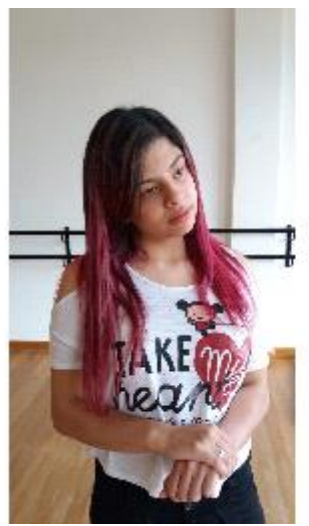

Quando eu vejo alguma garota que eu não conheço toda de intimidade com meu boy.

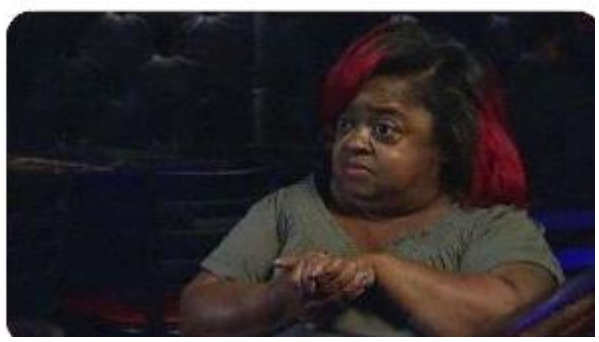

Figura 2. À esquerda a jovem realizando a pose para a imagem. À direita o meme escolhido por Taciane. Fonte: Registro dos autores. proposição da Dança Contempop no contexto escolar. Revista da FUNDARTE, Montenegro, p.222-241, ano 19, no 37, Janeiro/Março.

Disponível em: http://.seer.fundarte.rs.gov.br/index.php/RevistadaFundarte/index> 30 de março de 2019. 


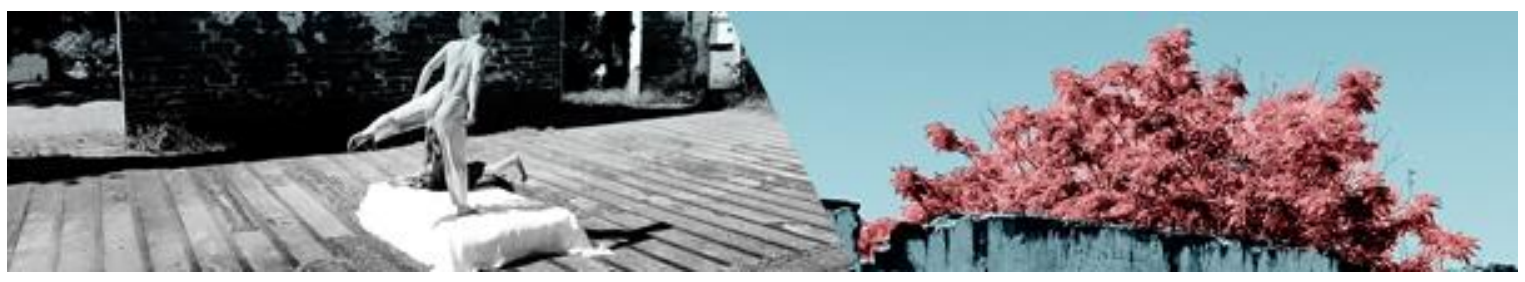

Taciane se deteve em reproduzir o que viu na imagem, já Brenda experimentou outras formas de pose para a imagem, ressignificando-a a partir da ideia que a imagem transmitiu. Esse cenário sugere uma diversidade de possíveis relações corpo-imagem a serem tecidas com a tarefa de criação. A heterogeneidade quanto à vida pessoal das adolescentes, por sua vez, aparece com tom de humor neste procedimento.

Outro tema que as duas jovens trouxeram foi a relação cotidiana com a escola e a forma de avaliação escolar. $\mathrm{Na}$ imagem a seguir (figura 3) é possível observar os memes escolhidos pelas intérpretes criadoras.

na sala de aula // fazendo a prova

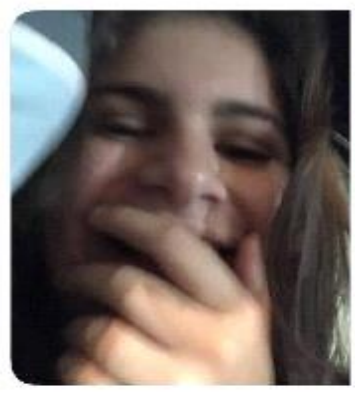

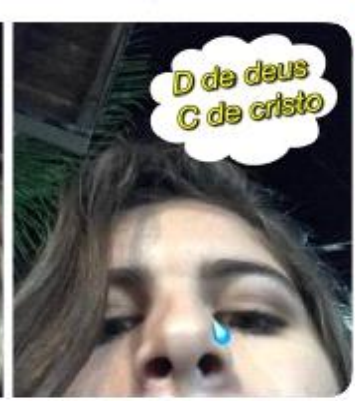

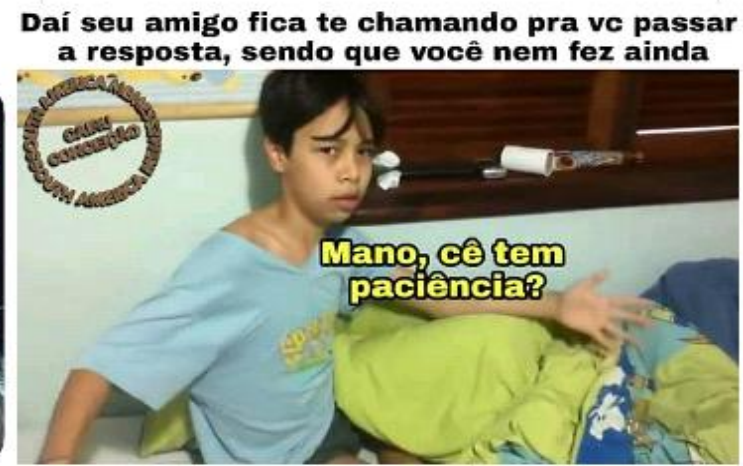

Figura 3. Memes escolhidos pelas alunas sobre a temática da escola. Fonte: Registro dos autores.

O quadro à esquerda refere-se ao cenário de tensão que é criado no momento de avaliação, em resposta aos modos de avaliação tradicionalmente adotados no fazer docente. O quadro à direita, por sua vez, reporta a "cola" que é repassada aos colegas a fim de fazer circular as respostas das questões de uma prova.

O terceiro procedimento foi realizado por fim com o uso de classes do mesmo modelo que as utilizadas na escola. A inspiração que tivemos para pensar no que depois se tornou a primeira cena de A Preço de Fábrica foi a obra Rosas danst Rosas (1997), da coreógrafa belga Anne Teresa de Keersmaeker. No vídeo há um momento em que todas as bailarinas, sentadas em cadeiras, fazem repetidamente movimentações do cotidiano, de forma alternada e às vezes simultânea. Outra referência usada é a obra Café Müller (1978) da coreógrafa alemã Pina Bausch, a qual envolve cadeiras espalhadas por todo o espaço e bailarinos que dançam enquanto NASCIMENTO Djenifer Geske; AIRES, Daniel; BARBOZA, Mônica Corrêa. A Preço de Fábrica: proposição da Dança Contempop no contexto escolar. Revista da FUNDARTE, Montenegro, p.222-241, ano 19, no 37, Janeiro/Março.

Disponível em: http://.seer.fundarte.rs.gov.br/index.php/RevistadaFundarte/index> 30 de março de 2019. 


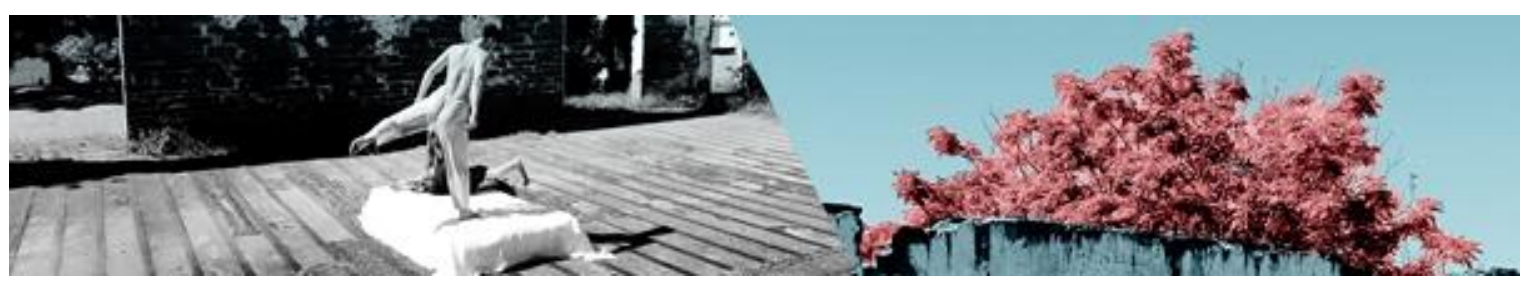

outros tiram cadeiras para não haver choques com os referidos elementos cênicos. Outro aspecto que nos inspira em Bausch é o uso de ações cotidianas e de repetições em suas composições.

No primeiro momento da criação as jovens ficaram sentadas, de olhos fechados e com as mãos em cima das classes. Demos algumas indicações para que lembrassem de como se constituía a distribuição espacial dos móveis nas salas de aula frequentadas por elas, desde a infância até aquele momento. Perguntamos como percebiam a mudança das classes da pré-escola para o primário e como isso estava ligado às relações estabelecidas entre alunos e professores; questionamos sobre quais lugares da sala de aula se situavam suas classes e o que isso significava para elas; pedimos para que se lembrassem do modo como se sentam nas classes em seus cotidianos e quais as ações mais recorrentes; solicitamos por fim que selecionassem as principais ações de modo a construir uma sequência em conjunto, com sugestões de seus movimentos, incentivando-as a experimentar ações a partir destas lembranças e das sensações que elas causavam.

Ao analisarmos o período de encontros vivenciados com as jovens estudantes tivemos algumas percepções acerca das implicações pedagógicas que este processo poderia nos trazer como educadores. Ao observá-las percebemos que o primeiro procedimento foi complexo de ser apreendido. À medida que os encontros avançaram as alunas se sentiram mais à vontade, especialmente nas duas últimas proposições, devido à familiarização com os temas. Ao nos depararmos com as percepções de Taciane, essa suposição se confirmou:

A coreografia feita em uma sala de aula com as classes foi a que mais gostei, achei muito divertida até porque foi a aula que a gente mais conseguia pensar em várias coisas que podíamos fazer, o método foi bem fácil porque é uma coisa do nosso dia a dia. (VIEIRA, 2018).

Para Taciane, o último procedimento foi o que mais a interessou, pois ele possuía maior relação com seu cotidiano. Foi possível, a partir disso, colher algumas pistas sobre o porquê de alguns alunos não se aproximarem da aula de Dança dentro da escola. Muitas vezes elas acabam dando a ideia de que são distantes da realidade NASCIMENTO Djenifer Geske; AIRES, Daniel; BARBOZA, Mônica Corrêa. A Preço de Fábrica: proposição da Dança Contempop no contexto escolar. Revista da FUNDARTE, Montenegro, p.222-241, ano 19, no 37, Janeiro/Março.

Disponível em: http://.seer.fundarte.rs.gov.br/index.php/RevistadaFundarte/index> 30 de março de 2019. 


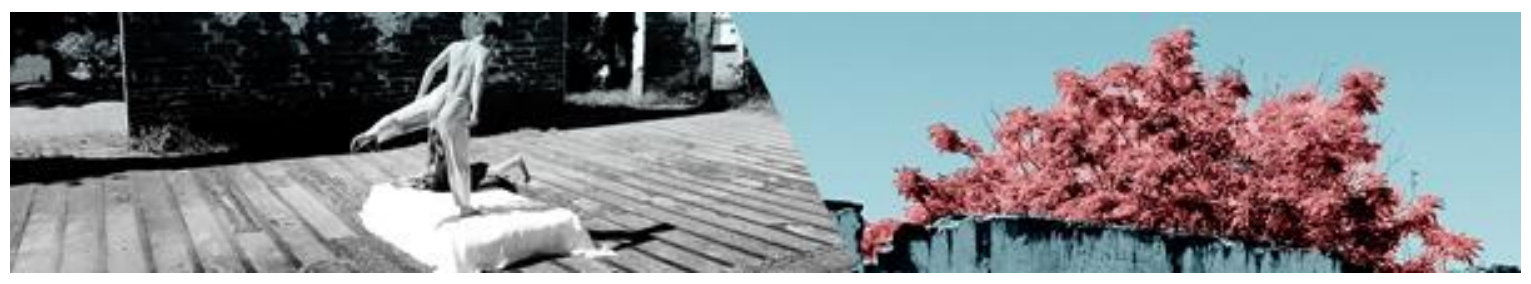

dos alunos, por conta do imaginário socialmente construído de que é preciso "nascer para dançar" para poder fazer uma aula de Dança.

Nesse cenário pudemos refletir que trabalhar a criação, tendo como ponto de partida a exploração de ações cotidianas, pode aproximar os alunos da prática de criação em Dança. Marques (2010) ao refletir acerca da Dança dentro da escola, já dizia que, para ler o mundo, o aluno precisa impregnar sentido ao que se está fazendo.

Brenda também afirmou ter se envolvido mais no último procedimento:

Essa dança com as mesas me fez lembrar algumas coisas que eu sentia em relação à escola, por isso foi o trabalho que eu me envolvi mais. Me fez pensar em como muitos professores então ali na frente de uma turma, pensando no dinheiro que vai receber e não no amor que tem pela profissão, certa que muitas não estão nem recebendo direito, mas estão ali porque se obrigam e não porque gostam do que fazem. (FLORES, 2018).

A aluna afirmou ter se envolvido mais na criação com as classes por conta das lembranças que foram acionadas, pois diziam respeito as suas vivências em relação à escola. A coreógrafa alemã Pina Bausch trabalhava com a criação em Dança a partir do estímulo de perguntas. Ela "fazia uma série de perguntas que remetiam os dançarinos às suas experiências de vida. Mergulhados em suas histórias e afetos, eles respondiam as perguntas de Pina com movimentos" (BERTÉ, 2015. p.56).

Brenda fez associações com as suas inquietações em relação ao ensino, a partir da criação com as classes escolares. Ao criar e compor Dança a partir das suas experiências dentro da sala de aula, construiu sentido ao que estava fazendo, pois falava do seu cotidiano, da sua vida.

Nos procedimentos dos memes as alunas também afirmaram possuir aproximação com a sua realidade, e que, ao mesmo tempo em que estavam criando, se divertiam a partir de uma tarefa simples - quando comparada ao primeiro procedimento. Brenda afirmou algo semelhante: "Me senti mais envolvida com o dos memes e com a dança das mesas, acho que foi porque foram os dois últimos trabalhos, então eu já estava acostumada com novidades". (FLORES, 2018). proposição da Dança Contempop no contexto escolar. Revista da FUNDARTE, Montenegro, p.222-241, ano 19, no 37, Janeiro/Março.

Disponível em: http://.seer.fundarte.rs.gov.br/index.php/RevistadaFundarte/index> 30 de março de 2019. 


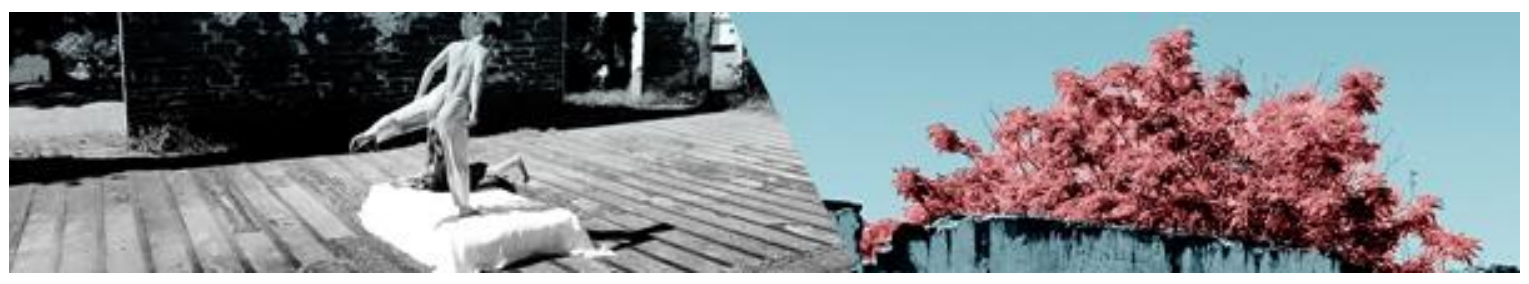

Ao falar sobre a experiência vivenciada no processo criativo como um todo, Brenda destaca:

Eu esperava que fosse uma experiência divertida, e realmente foi, mas a dança agora pra mim se tornou algo bem diferente, antes era só algo que tu tinha que decorar, mas eu vejo que tem muita coisa por trás, tem sentimentos, emoções, coisas que eu nem imaginava e foi incrível descobrir isso, descobrir que a partir de uma imagem eu podia criar movimentos pra uma coreografia. (FLORES, 2018).

O relato da jovem se aproxima do que almejamos em processos educativos em dança: ampliar o entendimento sobre o que é Dança e sobre como ela pode ser criada desenvolvendo a subjetividade humana, pautada no aspecto relacional de suas vivências. Taciane afirmou que superou suas expectativas em relação ao que achava que seria o processo criativo, ampliando seu entendimento acerca da criação em Dança:

Eu fiquei feliz com a oportunidade e com certeza superou todas as minhas expectativas, pois achei que eu ia só dançar, mas, além disso, eu aprendi muita coisa, fiz movimentos que nunca tinha feito, tive a experiência de ajudar a criar a coreografia. Tipo saber que tem um pouco de mim nas criações na coreografia é muito top, cara, top demais, tive algumas dificuldades em alguns movimentos, mas nada que depois eu não conseguisse fazer, então eu achei tudo incrível e todas as aulas maravilhosas. (VIEIRA, 2018).

A partir dos relatos escritos pelas meninas, podemos também refletir acerca do fazer docente e da importância tão necessária do professor aproximar-se dos saberes dos alunos. Sobre esse assunto Berté (2015) ressalta:

Ao evidenciar a importância da correlação arte e vida, do cotidiano, dos afetos, dos artefatos culturais consumidos, vistos e usados no dia a dia (e não apenas guardados em livros e manuais de arte, em museus, galerias e outros templos), a dança contempop investe em uma forma de educação estética que possibilita aos corposmídia ações sensíveis e afetivas de cuidado, preservação e transformação da cultura, do mundo, do outro. Uma educação estética que, antes dos regimes escópicos e dos códigos estéticos que doutrinam o olhar e a percepção, dê atenção às experiências estéticas que os sujeitos já vivenciam de modo prazeroso, inventivo e até subversivo, no intuito de estimulá-los a ampliar suas potencialidades perceptivas, críticas e criativas sem ter que, necessariamente, abandonar os artefatos, os artistas e as imagens com os quais se identificam. (BERTÉ, 2015. p.182).

NASCIMENTO Djenifer Geske; AIRES, Daniel; BARBOZA, Mônica Corrêa. A Preço de Fábrica: proposição da Dança Contempop no contexto escolar. Revista da FUNDARTE, Montenegro, p.222-241, ano 19, no 37, Janeiro/Março.

Disponível em: http://.seer.fundarte.rs.gov.br/index.php/RevistadaFundarte/index> 30 de março de 2019. 


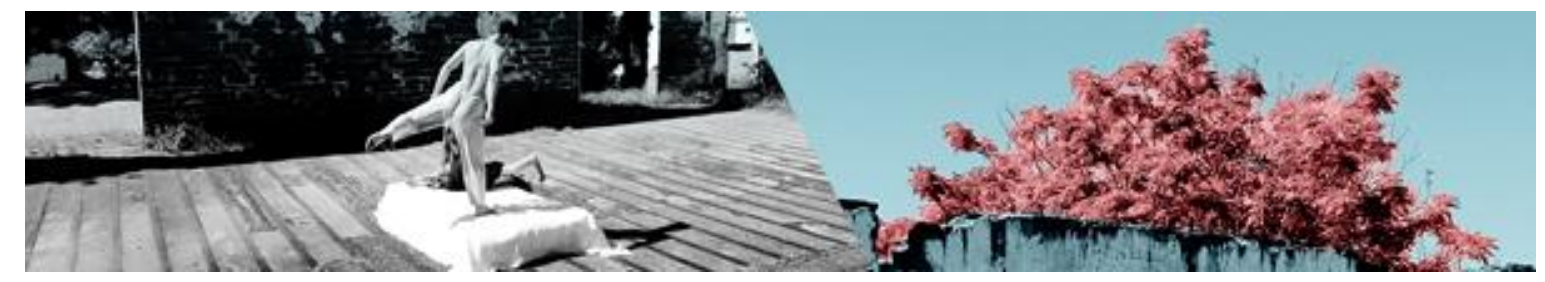

\section{Considerações finais}

Sobre os procedimentos de criação de A Preço de Fábrica, contextualizados neste artigo a partir da perspectiva da Dança Contempop, foi possível perceber uma maior motivação e mobilização das alunas para a criação, quando o contexto das mídias digitais e das redes sociais foi abordado. Os memes, sendo atualmente uma das grandes "febres da internet", puderam ser um meio de motivar os estudantes para a prática de Dança. O humor causado por esse fenômeno auxiliou na aproximação entre professores e alunos, ao mesmo tempo em que se pôde trabalhar com questões sociais/políticas/culturais implícitas nestas imagens.

O trabalho com as ações cotidianas foi outro aspecto abordado ao longo do processo criativo, auxiliando numa possível aplicação da Dança Contempop no universo escolar. A coreógrafa Pina Bausch, como já dito anteriormente, trabalhava nesta perspectiva, de modo a não limitar suas Danças a cascas encrustadas nos corpos dos bailarinos, propondo uma forma de criação cujo mote eram as suas experiências de vida.

As criações, muitas vezes resultavam em ações cotidianas, colocando conceituados críticos a se perguntarem sobre quais seriam as fronteiras que delimitariam ou não a Dança da linguagem do Teatro. Quando questionada sobre o porquê trabalhava com essa perspectiva, Bausch respondia: "eu não investigo como as pessoas se movem, mas o que as move" (CYPRIANO, 2005, p. 27). Interessava a Pina, os afetos dos bailarinos, suas experiências de vida. Na Dança Contempop, Bausch é uma forte referência e, portanto, um exemplo do que seria essa Dança Contemporânea que indaga e questiona. De acordo com Berté (2015):

A proposição Dança Contempop bebe no trabalho desenvolvido por essa coreógrafa como sua primordial fonte de referência de dança contemporânea. $\mathrm{O}$ vanguardismo de Pina Bausch em olhar para as experiências e para os afetos dos dançarinos, e entender isso como elemento gerador de dança, é o que move a dança Contempop a valorizar os diversificados modos como os corpos experimentam, usam, interagem como os artefatos culturais. (BERTÉ, 2015. p.55). 


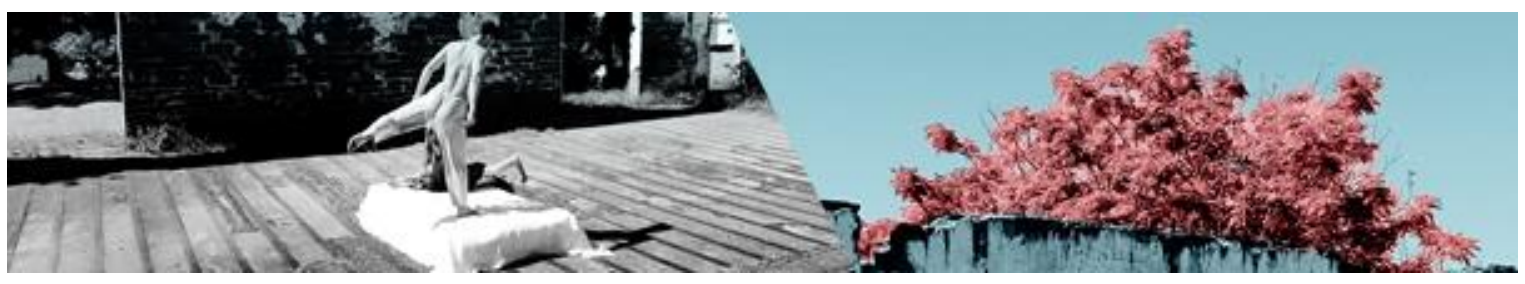

O autor ainda afirma que o modo como Pina procedia na criação em Dança o possibilitava fazer associações com o que Freire e Faundez (2008) trazem ao proporem uma "pedagogia da pergunta", considerada como uma forma de provocação. Os mesmos ainda comentam que "perguntar nem sempre é cômodo". "A pergunta incomoda, interrompe a linearidade, faz o processo adquirir outras nuances, acentua e flexibiliza a processualidade das relações". (FREIRE e FAUNDEZ, 2008, p.54).

Berté (2015) ainda explica que:

Os procedimentos criativos de Pina Bausch e a pedagogia da pergunta de Freire e Faundez (2008) fomentam a proposição de dança contempop nos modos como questionam, valorizam e trabalham com as experiências afetivas dos corpos. Os movimentos afetivos engendrados na relação corpo-ambiente e os movimentos de uso de imagens e artefatos culturais, aliados em movimentos de dança, são como que os pilares que estruturam a proposição crítica, criativa e pedagógica da dança contempop. (BERTÉ, 2015. p.87).

Bausch nos inspira, assim como Berté, a dar voz aos afetos e experiência de vida dos alunos quando se trata da criação em Dança. Acreditamos que este tipo de experiência dentro da escola pode transformar a relação de estudantes com a Dança. Trabalhar com ações cotidianas de algum contexto condizente à rotina diária dos alunos pode aproximar, sobretudo, aqueles mais tímidos e que não possuem vivências anteriores com Dança. Dar indicações para que se lembrem de fatos de sua vida e se remetam as ações daquele momento materializando-as em seus corpos, pode ser uma boa forma de abordar o Contempop dentro da escola.

A condução dos procedimentos de criação também foi decisiva para inferirmos que quanto mais simples e direcionadas forem as primeiras tarefas, menos serão geradas tensões ou falas que deflagram alguma reação negativa, como "não sei fazer isso" ou "não sei dançar". Julgamos interessante pensar na progressão didática na criação, de forma que, quanto mais aproximado das vivências do aluno no início, mais seguro ele tenderá a se sentir. Pedir para que os alunos façam poses para as imagens pode ser uma boa alternativa, assim como dar indicações que podem ir se complexificando conforme o aluno vá se ambientando com a proposta. proposição da Dança Contempop no contexto escolar. Revista da FUNDARTE, Montenegro, p.222-241, ano 19, no 37, Janeiro/Março.

Disponível em: http://.seer.fundarte.rs.gov.br/index.php/RevistadaFundarte/index> 30 de março de 2019. 


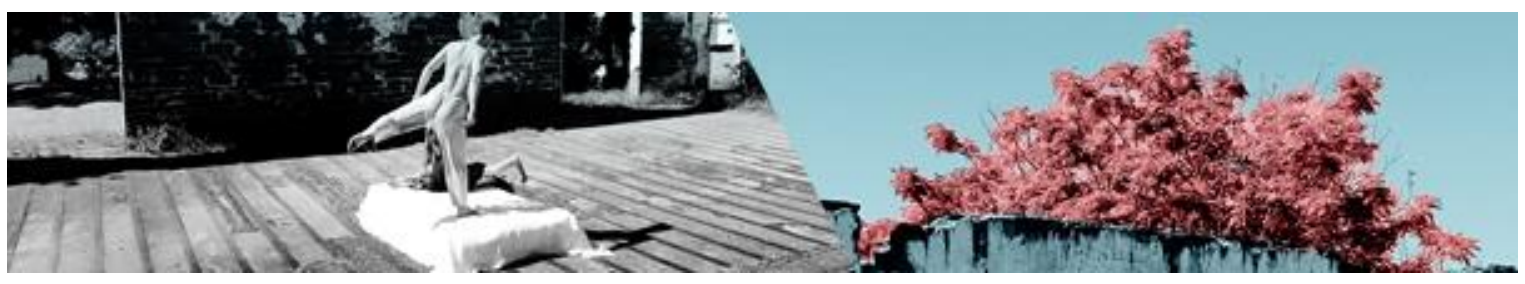

A referida experiência ocorreu com duas estudantes, formato que se daria de modo totalmente diferente com um maior número de alunos dentro da escola e do currículo escolar. A criação realizada com uma turma de 30 alunos, por exemplo, poderia dificultar que 0 professor/propositor destinasse uma atenção mais individualizada a cada participante, tendo em vista que a criação muitas vezes demanda exercícios individuais e/ou em grupos.

Brenda e Taciane consomem uma cultura visual semelhante, o que seria diferente se a experiência tivesse ocorrido dentro do currículo escolar, frente à pluralidade encontrada em uma turma mista. Diante dessa diversidade, acreditamos ser relevante encontrar formas adequadas de contemplar a todos e estimular o diálogo entre as diferentes leituras de mundo aí presentes. Esses aspectos são levantados no intuito de ressaltar que o contexto e as circunstâncias de cada sujeito e instituição escolar são determinantes na forma como irá se dar a criação. Frente a esse quadro especulativo, nos questionamos: o referido experimento ocorreu com meninas inseridas em um contexto urbano, mas como seria se ocorresse com jovens da zona rural? Como se daria um experimento realizado somente com meninos? E numa escola mais periférica? São fatores que se articulam com as imagens consumidas pelos jovens e 0 modo com que se relacionam com a proposição.

A Dança Contempop mostrou ser facilmente aproximada da cultura juvenil, justamente pela forte relação que os jovens possuem com as imagens de memes, vídeos do YouTube, selfies, boomerangs, gifs, etc., fontes marcantes de imagens consumidas no cotidiano da juventude do século XXI e fatores importantes de serem levados em conta na proposição de Danças na escola.

\section{Referências:}

BOGDAN, R.C. BIKLEN, S.K. Investigação qualitativa em educação. Porto: Porto editora, 1994.

BERTÉ, O. Dança Contempop: corpos, afetos e imagens (mo)vendo-se. Santa Maria: Editora UFSM, 2015.

NASCIMENTO Djenifer Geske; AIRES, Daniel; BARBOZA, Mônica Corrêa. A Preço de Fábrica: proposição da Dança Contempop no contexto escolar. Revista da FUNDARTE, Montenegro, p.222-241, ano 19, no 37, Janeiro/Março.

Disponível em: http://.seer.fundarte.rs.gov.br/index.php/RevistadaFundarte/index> 30 de março de 2019. 


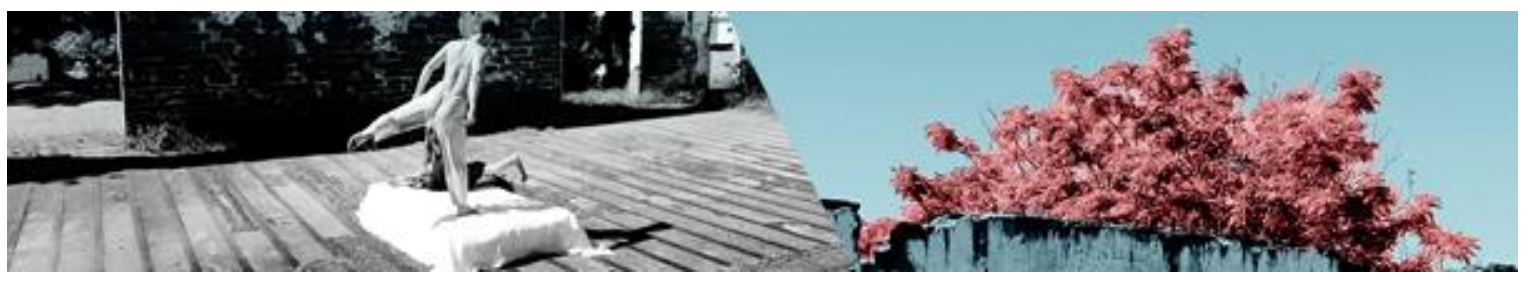

CYPRIANO, F. Pina Bausch. São Paulo: Cosac Naify, 2005.

DAMÁSIO, A. O mistério da consciência: do corpo e das emoções ao conhecimento em si. São Paulo: Companhia das Letras, 2009.

DANTAS, M. A pesquisa em dança não deve afastar o pesquisador da experiência da dança: reflexões sobre escolhas metodológicas no âmbito da pesquisa em dança. Revista da FUNDARTE. n.13/14, janeiro/dezembro, 2007, p. 13-18.

DIAS, B; IRWIN, R. L. Pesquisa Educacional Baseada em Arte: A/r/tografia. Santa Maria: Ed. Da UFSM, 2013.

FLORES, B. Registro em diário de processo criativo. Produzido em 10 de outubro de 2018.

FREIRE, P. Pedagogia da autonomia: saberes necessários à prática educativa. São Paulo: Paz e terra, 1996.

. Pedagogia do oprimido. 17ª ed. São Paulo: Paz e Terra, 1970.

FREIRE, P; FAUNDEZ, A. Por uma pedagogia da pergunta. 6ª ed. Rio de Janeiro: Paz e Terra, 2008.

KATZ, H. O corpo como mídia de seu tempo: a pergunta que o corpo faz. In: Rumos Itaú Cultural Dança. São Paulo: Itaú Cultural, 2004. CD-ROM.

MARQUES, I. BRAZIL, F. Arte em Questões. São Paulo: Digitexto, 2012.

MARQUES, I. Linguagem da Dança: Arte e ensino. São Paulo: Digitexto, 2010.

OSTERWOLD, T. Pop Art. Hong Kong, China: Taschen, 2011.

ROCHA, T. Por uma docência com dança contemporânea. In: GOLÇALVES, T.; BRIONES, H.; PARRA, D.; VIEIRA, C. (Org.). Docência-artista do artista-docente: Seminário Dança teatro Educação. Fortaleza: Expressão Gráfica e Editora, 2012, p. 3249. 


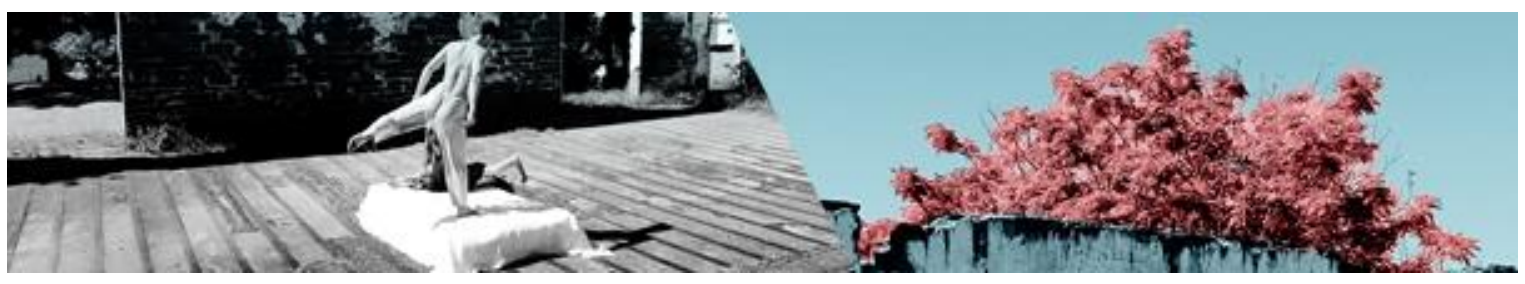

SILVA, L.E. Autonomia como princípio educativo. n. 101. Revista espaço acadêmico, 2009.

TOMAZZONI, A. A escola e o aluno da Dança: desafios da contemporaneidade. IN: ICLE, G. (Org.). Pedagogia da Arte. Porto Alegre: Editora da UFRGS, 2010.

TOURINHO, I. Imagens, pesquisa e educação: questões éticas, estéticas e metodológicas. In: MARTINS, R; TOURINHO, I. (Org). Cultura das imagens: desafios para a Arte e para a educação. Santa Maria: Editora UFSM, 2012. p.231-252.

TOURINHO, I; MARTINS, R. Reflexividade e pesquisa empírica nos infiltráveis caminhos da cultura visual. In: MARTINS, R; TOURINHO, I. (Org). Processos e práticas de pesquisa em cultura visual e educação. Santa Maria: Editora UFSM, 2013.p. 61-76.

VIEIRA, T. Registro em diário de processo criativo. Produzido em 10 de outubro de 2018. 